\title{
Socioeconomic profile of cassava flour producers: a study on Vila de Igarapé-Açu, Capitão Poço, Pará, Brazil
}

\author{
Samara Ketely Almeida de Sousa ${ }^{1 *}$, Helen Patrícia Moreira Negrão ${ }^{1}$, Letícia do Socorro Cunha ${ }^{2}$, Thiago \\ Feliph Silva Fernandes ${ }^{3}$, Júlia Karoline Rodrigues das Mercês ${ }^{3}$, Wanderson Cunha Pereira ${ }^{4}$, Edmilson \\ Barbosa do Nascimento ${ }^{1}$, Marlon Sheldon da Silva Galdino ${ }^{1}$ and Amanda Catarine Ribeiro da Silva ${ }^{1}$
}

\author{
${ }^{1}$ Federal Rural University of the Amazon, Capitão Poço, PA, Brazil. \\ ${ }^{2}$ State University of Western Paraná, Marechal Cândido Rondon, PR, Brazil. \\ ${ }^{3}$ Paulista State University Júlio Mesquita de Filho, Jaboticabal, SP, Brazil. \\ ${ }^{4}$ Federal University of Pará, Bragança, PA, Brazil. \\ *Author for correspondence: samarasousa664@gmail.com
}

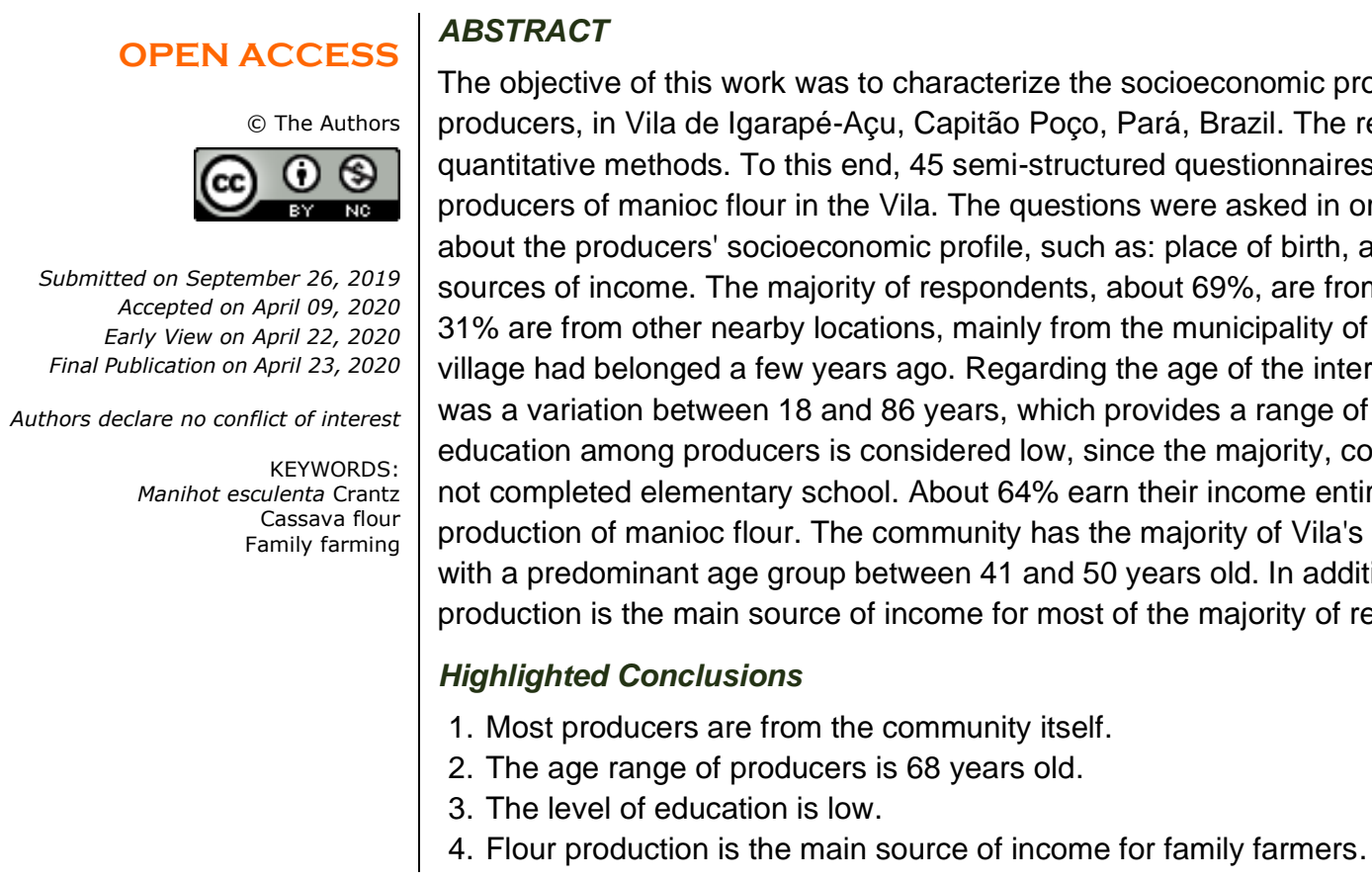

\section{INTRODUCTION}

Family farming produces most of the food that supplies the Brazilian table. About 70 percent of these are produced on small family farms, guaranteeing food sovereignty in the country (Gaboardi Júnior 2013).

Generally, producers who fall into family farming have small areas, that is, they are small producers, who produce different cultures with little technology and with the presence of family labor. Thus, these producers do not have access to the newest technologies and, with this, obtain low productivity in their activities, both agriculture and livestock (Minatel and Bonganha 2015).

Very cultivated nationally, $87 \%$ of the cassava (Manihot esculenta Crantz) produced in Brazil in 2009, according to the Brazilian Institute of Geography and Statistics - IBGE, came from family producers. It is a shrub, perennial, heliophite plant (Fraife Filho and Bahia 2009) belonging to the Euphorbiacea family, originally from Tropical America (lyer et al. 2010). It has the physiological characteristic of synthesizing starch in the leaves by storing it in the roots. It is an important crop worldwide due to its good adaptability to different environments, rusticity and low soil fertility requirements (Tironi et al. 2015). For having such characteristics, many family farmers cultivate it and one way to add value to the product is the production of flour and other by-products such as tapioca gum, tucupi and beijú.

Culture presents itself as one of the most appreciated foods by Brazilians, especially in the North and Northeast regions (Portella 2015). In the North Region, in addition to being an admirable source of food for the population, it 
is also an economic activity for a large part of the producers, mainly family-based. The crop is grown in small areas, making it possible to diversify production on the properties. The State of Pará is the main producer, both in the Region and in the Country, with 4.8 million tons produced in 2008 (IBGE 2010).

In Igarapé-Açu, a village belonging to the municipality of Capitão Poço, Pará, currently has 412 families and the production of manioc flour is already part of the cultural identity, an activity that is passed on from generation to generation. Several studies address the cultural identity of a locality with scientific knowledge, this association is called Ethnocentrism, which addresses the knowledge of the traditional populations of a locality about their natural processes, trying to discover the logic underlying the knowledge and profiles of those who visit them. use. For Ribeiro (2012), traditional knowledge has been essential to analyze the paradigms of colonial and agricultural development models and serve as a basis for the design of new alternative models.

For many years, this activity has been the main source of income for family farmers resident in the Vila. Thus, the objective of this work was to characterize the socioeconomic profile of cassava flour producers, in Vila de Igarapé-Açu, Capitão Poço-Pará.

\section{MATERIAL AND METHODS}

The research was carried out in Vila de Igarapé-Açu, belonging to the municipality of Capitão Poço, $25 \mathrm{~km}$ away from the city center (Figure 1). According to the Municipal Health Secretariat, the village has 412 families and is closer $(8 \mathrm{~km})$ to the municipality of Ourém, which belonged for many years. After the creation of the municipality of Capitão Poço, in December 1961, it became part of the boundaries of this municipality.

The research involved quali-quantitative methods. To this end, 45 semi-structured questionnaires were applied to all producers of manioc flour in the Vila. The questions were asked in order to obtain information about the producers' socioeconomic profile, such as: place of birth, age, education level and sources of income.

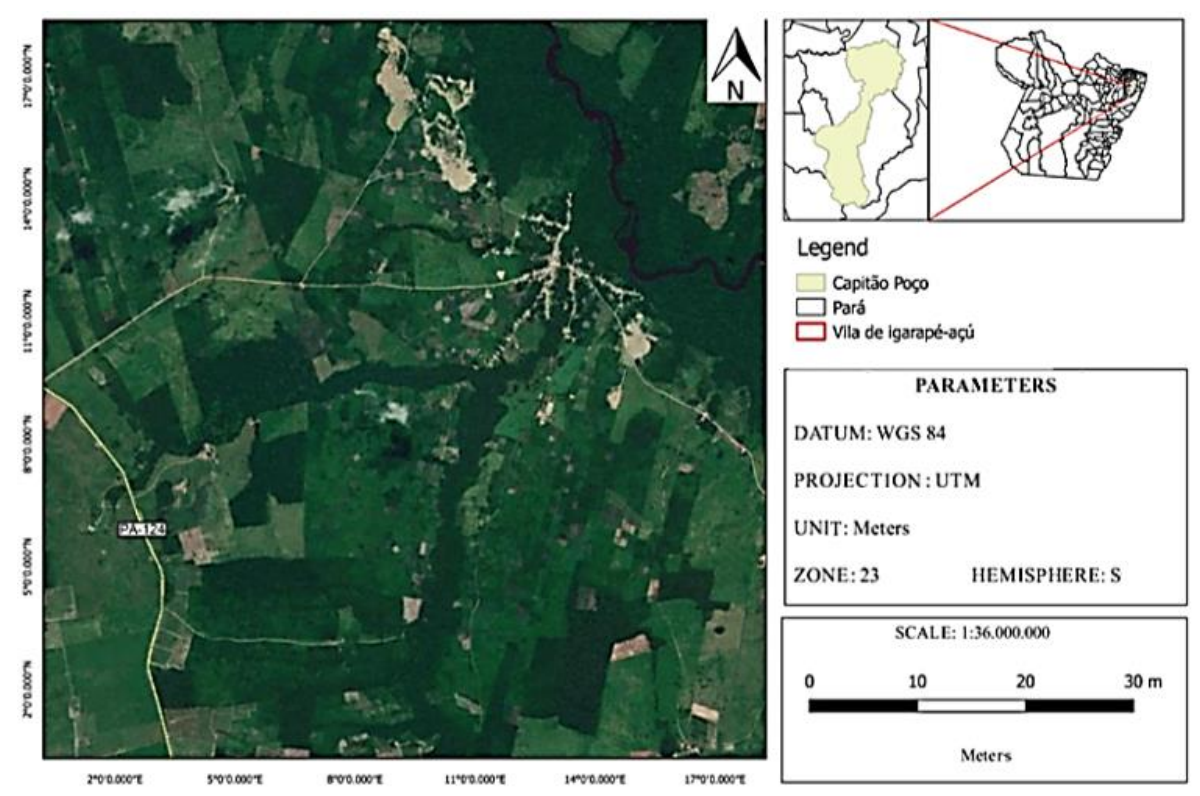

Figure 1. Geographic location of the Igarapé-Açu community, in the municipality of Capitão Poço / PA - Brazil.

The data obtained were analyzed and interpreted with the aid of electronic spreadsheets, using Microsoft Excel $2010 \circledast$ software.

\section{RESULTS AND DISCUSSION}

Figure 2 shows the naturalness of the cassava producers in the village of Igarapé-Açu, who dedicate their activities to the cultivation of cassava and production of flour. The majority of respondents, about $69 \%$, are from the village and only $31 \%$ are from other nearby locations, mainly from the municipality of Ourém, to which the village had belonged a few years ago. For Santos and Santana (2012), this low spatial and temporal mobility, in large part, is attributed to family ties, since they live in the same place because the parents are already in the area or, after having married.

Regarding the age of the producers (Figure 3) interviewed, there was a variation between 18 and 86 years, which provides a range of 68 years. Of the total respondents, only $13 \%$ are between the age group of 18 to 30 
years, a result that reveals the small participation of young people in the activity studied, $16 \%$ are between 31 and 40 years old and $31 \%$ are between 41 and 50 years, representing the highest percentage and showing that cassava production involves older producers, but still has the strength to work, since this service requires a lot of physical strength and is also related to the role of the producer as leader of the family (father). Of the remainder, only $20 \%$ are between 50 and 60 years old and $20 \%$ are over 61 years old.

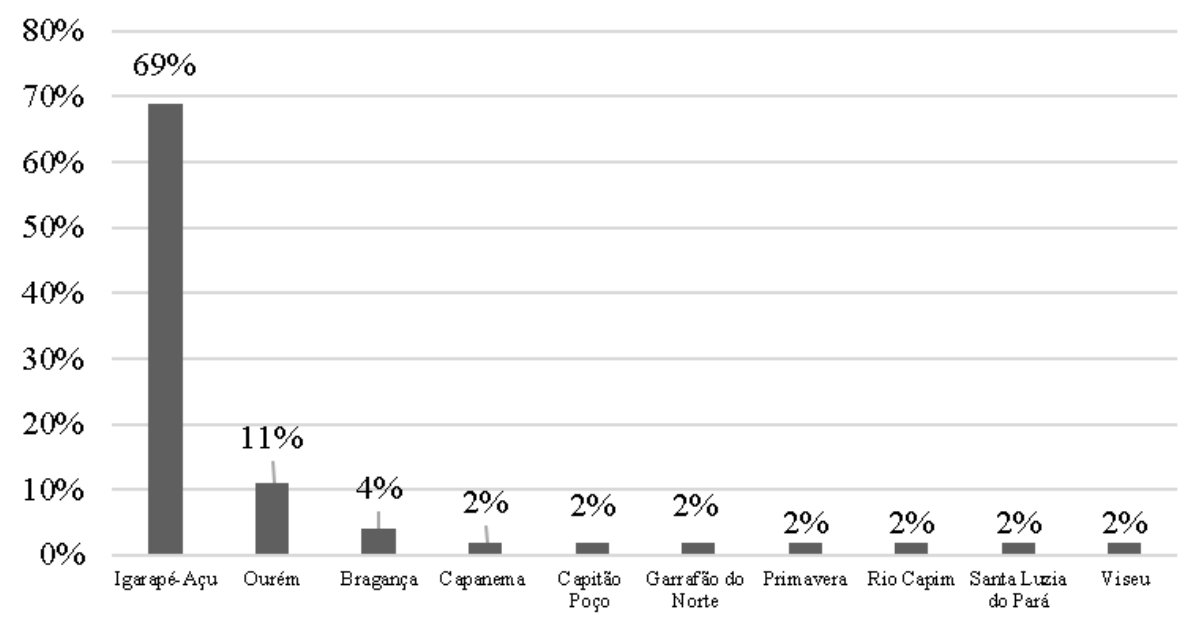

Naturalness of the producers

Figure 2. Interviewees from the Igarapé-Açu community, in the municipality of Capitão Poço / PA - Brazil.

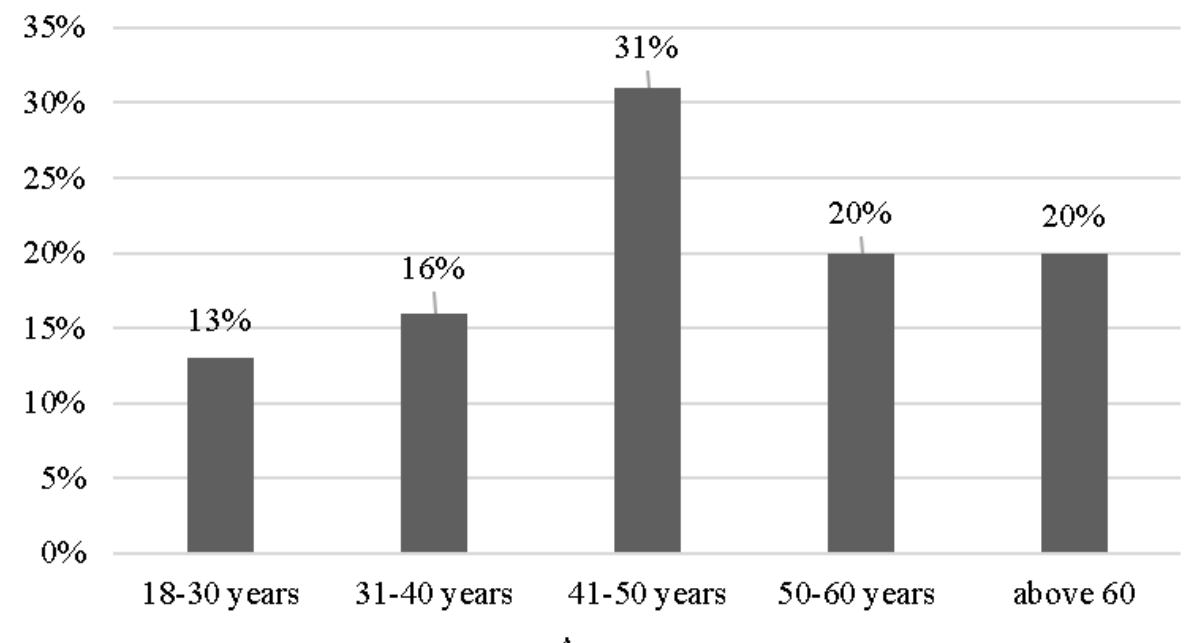

Age range

Figure 3. Age range of respondents from the Igarapé-Açu community, in the municipality of Capitão Poço / PA - Brazil.

Similar results were observed by Tarsitano (2005), who found that the age group of young people presents a lower percentage when observed in relation to the largest age groups. This is related to the occupation of the children of producers in other activities such as study or work in other sectors, outside the rural sector, which from the point of view of social reproduction is very worrying, according to the author.

Of the interviewees, $87 \%$ are over 31 years old, showing that the youngest people in the Vila are looking for other professional activities, such results may have a negative influence on the future of the village of Igarapé-Açu.

Figure 4 shows that the level of education among producers is considered low, since the majority, corresponding to $73 \%$, have not completed elementary school, $11 \%$ have completed high school, $9 \%$ have incomplete high school, $5 \%$ they have completed elementary school and only $2 \%$, which corresponds to one person, is illiterate.

The village does not have a high school, which can be one of the difficulties when entering and concluding. The schools currently present are from literacy to the 8th grade. However, until 2006, the elementary education offered was only up to the 5th year. To conclude their studies, students have the service offered by the city hall, by means 
of school buses, which transport them to the municipality of Capitão Poço to study in schools located in the city. In addition, some residents of the village prefer to go to the municipality of Ourém, which is closest to the same, to study and complete their high school.

Such difficulties are shown as obstacles to the conclusion of the studies of these producers. However, as noted, most of these already have a higher age group (Figure 3), a factor that makes it evident that a few years ago the completion of high school was a much greater difficulty than that observed in the village today, since, somehow, access to studies is easier than a few years ago.

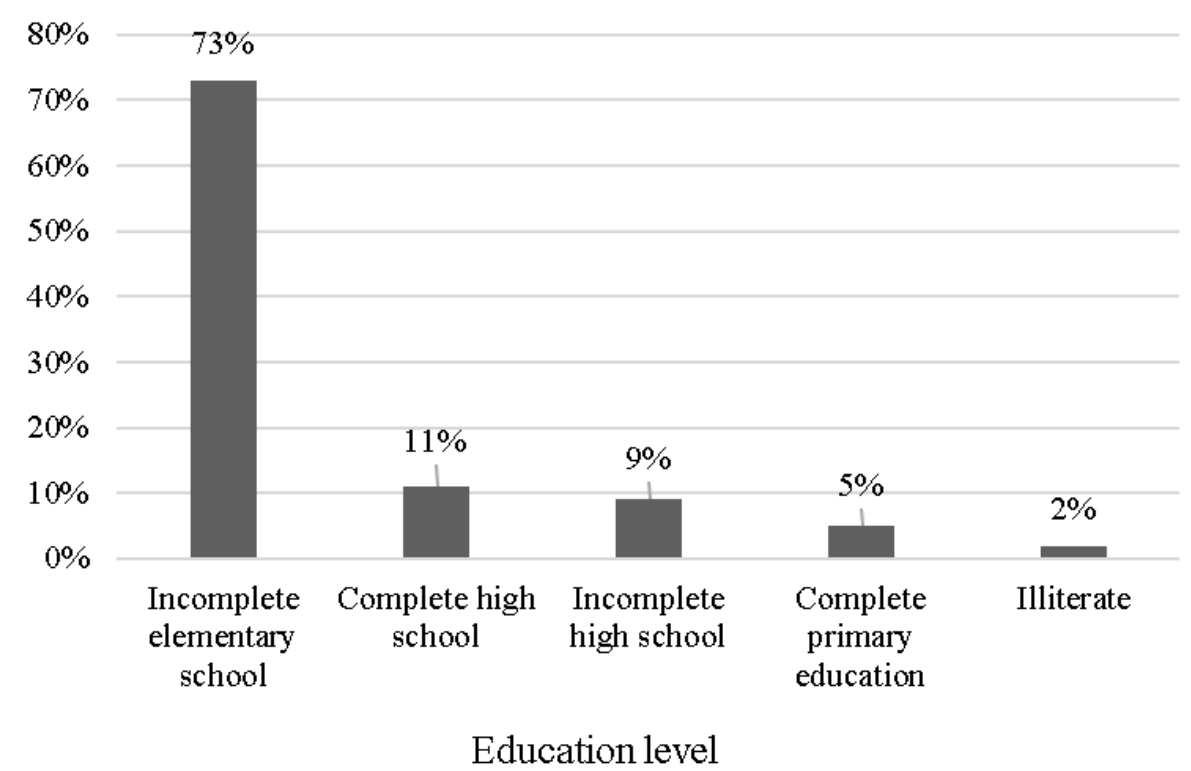

Figure 4. Education level of respondents from the Igarapé-Açu community, in the municipality of Capitão Poço / PA - Brazil.

Figure 5 shows that the majority of producers, around $64 \%$, earn their income entirely through the production of cassava flour, $14 \%$ have a pension, $11 \%$ have other sources of income, in addition to flour production, such as fishing , commerce, carpentry, municipal service and / or other productions in the scope of agriculture, with an emphasis on fruit growing, production of black pepper, beans and corn, $7 \%$ acquire most of the income through the production of black pepper kingdom and cassava, and only $4 \%$ participate in social programs of the Federal Government, such as Bolsa Família.

In general, all respondents earn an income through the sale of manioc flour, however, of the 45 producers interviewed, 29 have the activity of producing flour as the main source of income, which shows the relevance of this activity in the context community.

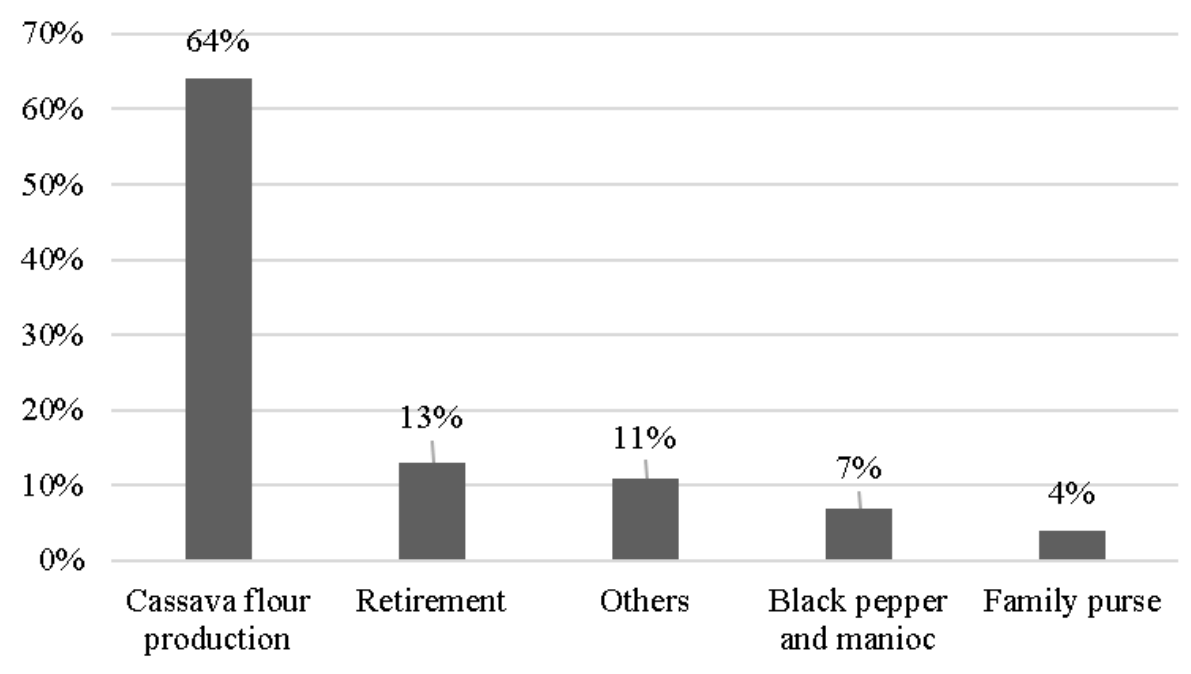

Source of income

Figure 5. Income sources of respondents from the Igarapé-Açu community, in the municipality of Capitão Poço / PA - Brazil. 
These results are similar to those shown by Santos and Santana (2012), in which the producers of cassava flour in the municipality of Portel, report that the main source of income for the interviewed families comes from the production of cassava flour. Secondly, the resources come from the Bolsa Família Program.

None of the interviewed producers has any professional qualification for the production of manioc flour. In addition, they opted for this activity due to their parents' influence. With this, we can affirm that, despite having no professional qualification, ethno-knowledge was the source of empirical qualification, since the knowledge acquired over time, and which is passed on, is the main knowledge tool of these farmers. Mendes et al. (2016) observed results similar to this research, when observing agricultural activities being reproduced from generation to generation.

Regarding the producers' income source for Santos and Santana (2012), the low diversification of production subjects' local farmers to great risks, whether due to the incidence of climatic and phytosanitary problems, or problems related to the market and commercialization, causing financial losses for the producer.

As reported by farmers in the village, due to fluctuations in the price of flour, there are times when the amount paid for the product overlaps with the producer's expenses. Therefore, they look for other sources of income and, as they say, they make "beaks" to compose the income.

In conclusion, the community has the majority of natural flour producers in the village, with a predominant age group between 41 and 50 years old. The education level of producers is low, with at least $73 \%$ without complete elementary education. In addition, cassava flour production is the main source of income for most of the majority of respondents.

\section{Acknowledgements}

To all the authors involved in the construction of this study, for the effort and patience in the referred work, and especially to the small producers of manioc flour, for having shared the reality lived in the field and passed on all the knowledge and information that were essential for the construction of the research.

\section{References}

Fraife Filho GA, Bahia JJS. 2019. Mandioca. Available at: <http://www.ceplac.gov.br/radar/mandioca.htm>. Accessed on May 14, 2019.

Gaboardi Júnior A. 2013. A importância da produção na agricultura familiar para a segurança alimentar. Universidade Federal do Paraná. 2 jornada questão agrária e desenvolvimento. 2013.

IBGE. 2010. Sistema IBGE de recuperação automática. 2008. Available

at:<http://www.sidra.ibge.gov.br/bda/tabela/protabl2.asp?z=t\&o=23\&i=P>. Accessed on: May 14, 2019.

lyer $S$ et al. 2010. Study of the early events leading to cassava root postharvest deterioration. Tropical Plant Biology 3:151-165.

Mendes VQ et al. 2016. Avaliação da cadeia produtiva da mandioca para farinha de mesa na Vila de Igarapé-Açu, Capitão Poço,

Pará. Cadernos de Agroecologia 10, 5p.

Minatel, J. F.; Bonganha, C. A. Agronegócios: a importância do cooperativismo e da agricultura familiar agribusiness: the importance of the cooperative and family farming. Emprededorirmo, Gestão e Negócios, v. 4, n. 4, 2015.

Portella AL. 2015. Caracterização do processo produtivo, aspectos da qualidade da farinha de mandioca e percepção dos agentes da cadeia na região central do Estado de Roraima. Tese (Mestrado profissional em Defesa Sanitária Vegetal) - Universidade Federal de Viçosa.

Ribeiro SC. 2012. Etnogeomorfologia sertaneja: proposta metodológica para a classificação das paisagens da sub-bacia do rio Salgado- CE. Tese (Doutorado em Geografia) - Universidade Federal do Rio de Janeiro.

Santos MAS, Santana AC. 2012. Caracterização socioeconômica da produção e comercialização de farinha de mandioca no município de Portel, arquipélago do Marajó, Estado do Pará. Revista Verde 7:73-86.

Tarsitano MAA et al. 2005. Caracterização e perspectivas da pecuária leiteira e a agricultura familiar. In: 43 Congresso da Sociedade Brasileira de Economia, Administração e Sociologia Rural, Ribeirão Preto, São Paulo.

Tironi LF et al. 2015. Desempenho de cultivares de mandioca em ambiente subtropical. Bragantia 74:58-66. 